\title{
Erratum to: Cytoarchitectural differences of myoepithelial cells among goat major salivary glands
}

\author{
Yaser Hosny Elewa • Mohammad Hafez Bareedy • Ahmed Awad Abuel-Atta • \\ Osamu Ichii • Saori Otsuka • Tomonori Kanazawa • Shin-Hyo Lee • \\ Yoshiharu Hashimoto • Yasuhiro Kon
}

Published online: 15 September 2010

(C) Springer Science+Business Media B.V. 2010

\section{Erratum to: Vet Res Commun}

DOI 10.1007/s11259-010-9427-9

The original version of this article unfortunately contained an incorrect author name.

The correct name of Ahmed Awad Abu Al Atta should be Ahmed Awad Abuel-Atta.

The online version of the original article can be found at http://dx.doi.org/10.1007/s11259-010-9427-9.

$\overline{\text { Y. H. Elewa } \cdot \text { O. Ichii } \cdot \text { S. Otsuka }} \cdot$ T. Kanazawa $\cdot$ S.-H. Lee $\cdot$ Y. Hashimoto $(\bowtie) \cdot$ Y. Kon

Laboratory of Anatomy, Department of Biochemical Sciences, Graduate School of Veterinary Medicine, Hokkaido University, Sapporo 060-0818, Japan

e-mail: hashimo@vetmed.hokudai.ac.jp

Y. H. Elewa • M. H. Bareedy • A. A. Abuel-Atta

Department of Histology and Cytology, Faculty of Veterinary Medicine,

Zagazig University, Zagazig 44519, Egypt 